\title{
MASTER
}

\section{1-GWh Diurnal Load-Leveling Superconducting Magnetic Energy Storage System Reference Design Appendix B: Cost Study, High-Purity Aluminum Production}


LA-7885-MS, Vol. III

Informal Report

UC-20b and UC-94b

Issued: September 197

\section{1-GWh Diurnal Load-Leveling Superconducting \\ Magnetic Energy Storage System Reference Design \\ Appendix B: Cost Study, High-Purity \\ Aluminum Production \\ C. N. Cochran* \\ R. K. Dawless* \\ J. B. Whitchurch*}

\section{MASTER}

"Aluminum Company of America, Alcoa Laboratories, Alcoa Center, Pittsburgh, PA 15069.
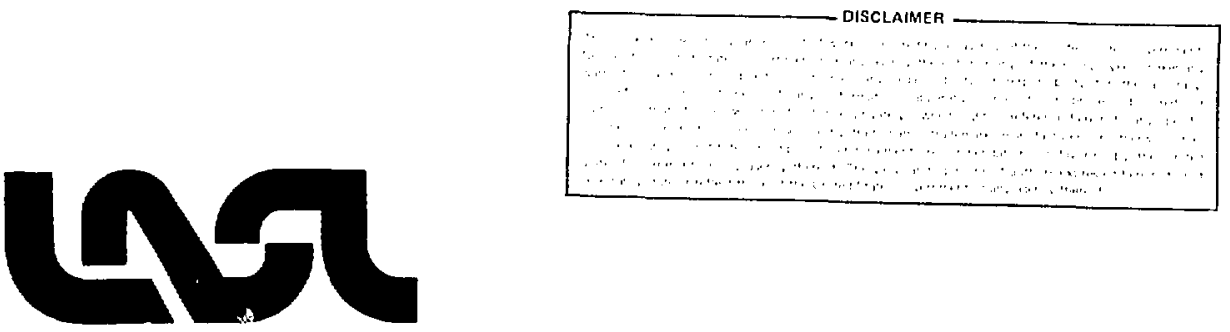
1-GWh DIURNAL LOAD-LEVELING SUPERCONDUCTING MAGNETIC ENERGY STORAGE SYSTEM REFERENCE DESIGN

APPENDIX B

COST STUDY, HIGH-PURITY ALUMINUM PRODUCTION

by

C. N. Cochran, R. K. Dawless, and J. B. Whitchurch

\section{ABSTRACT}

This report provides the final results for the University of California, Los Alamos Scientific Laboratory of a cost study on producing high-purity aluminum. Cost information is supplied for aluminum with purities of 200,2000 , and 5000 residual resistivity ratio. Two production situations were used for each purity: (1) $1 \times 10^{6} \mathrm{~kg} / \mathrm{yr}$ production rate with a 30-yr sustaining market and (2) I $\times 10^{6} \mathrm{~kg} / \mathrm{yr}$ production rate for 2 yrs only. These productions and purities are of interest for manufacturing devices for Superconducting Magnetic: Energy Storage. The cost study results are presented as a range and include (1) the selling price of the aluminum for each case, (2) the cost of facilities including construction, engineering, and related costs, (3) the cost of money and depreciation (interest/amortization), and (4) the energy costs--the total of power and fuel. The range is affected by possible production variations and other uncertainties. Information is also given on plant location options and the preferred feed to the purification facility (with ore source effects). The results of these studies indicate that extreme purity aluminum can be produced and sold for much lower prices than the current market situation would indicate. 
DISCUSSION AND RESULTS

\section{A. Purity Requirements}

The purity of aluminum for the Superconducting Magnetic Energy Storage (SMES) application will be determined by the residual resistivity ratio (RRR), which is the resistivity of the aluminum at $298 \mathrm{~K}$ divided by the resistivity at $4.2 \mathrm{~K}$. The purification processes considered for this study will reduce impurities to levels where the RRR specifications are met. The resistivity contribution of impurities in aluminum at $4.2 \mathrm{~K}$ as a function of atomic number is given in Fig. B-1. The transition elements, especially manganese and chromium, are particularly critical for this application.

The expected concentration of each impurity and its total resistivity contribution are given in Table B-I for the three purity cases. A 200-RRR product using Aluminum Company of America proprietary processing would have an overall purity level ranging from 99.993 to $99.995 \%$ whereas 2000-RRR metal would range from 99.999 to $99.9992 \%$, and 5000 RRR would be at least $99.9997 \%$ aluminum. These definitions do not include impurities such as axygen, nitrogen, etc., which are believed to have little effect on the RRR.

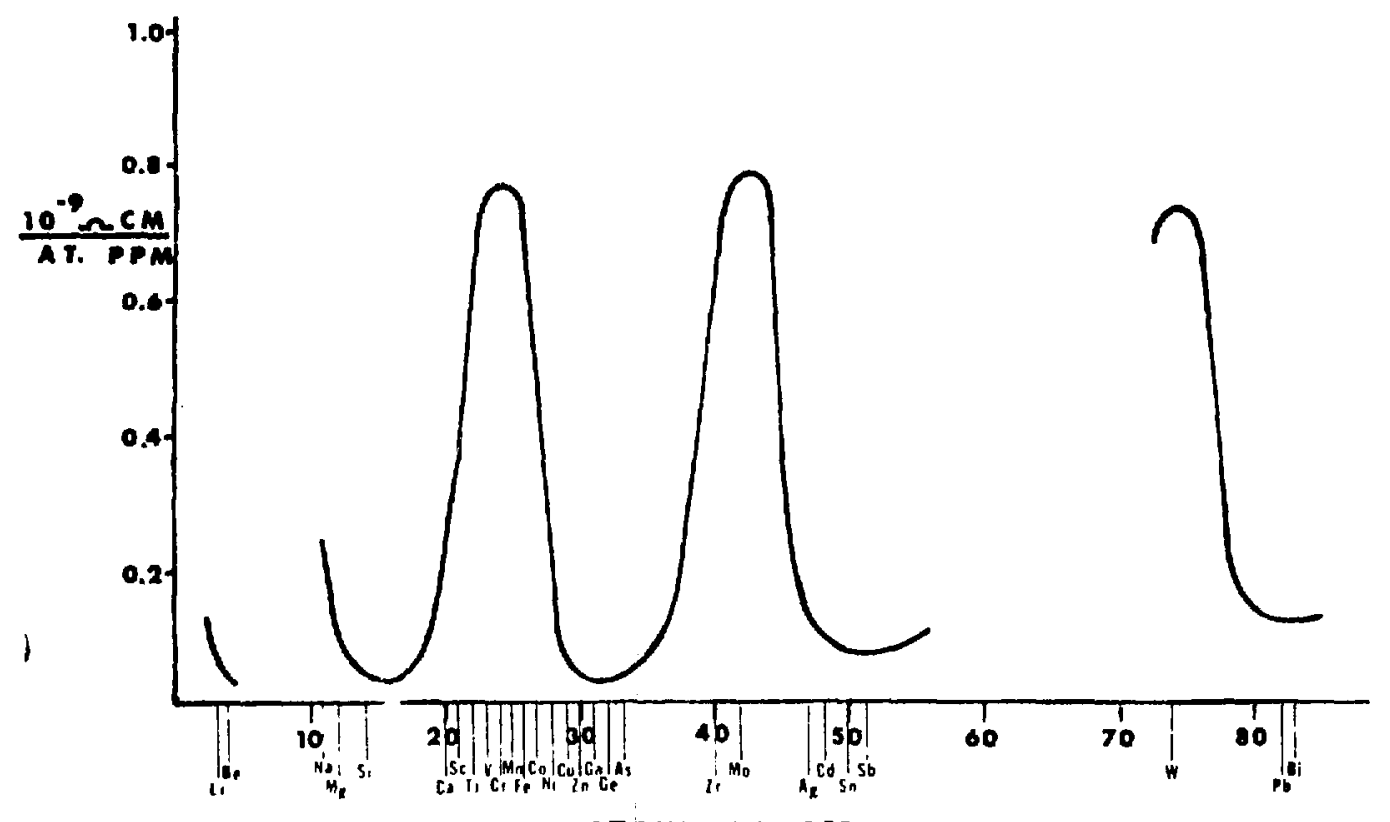

ATOMIC NUMBER

Fig. B-1.

Resistivity contributions for various elements in aluminum at $4 \mathrm{~K}$. 
TABLE B-I

ALUMINUM IMPURITY LEVELS FOR 200-RRR, 2000-RRR, and 5000-RRR PRODUCTS

Nominal Product Compositions

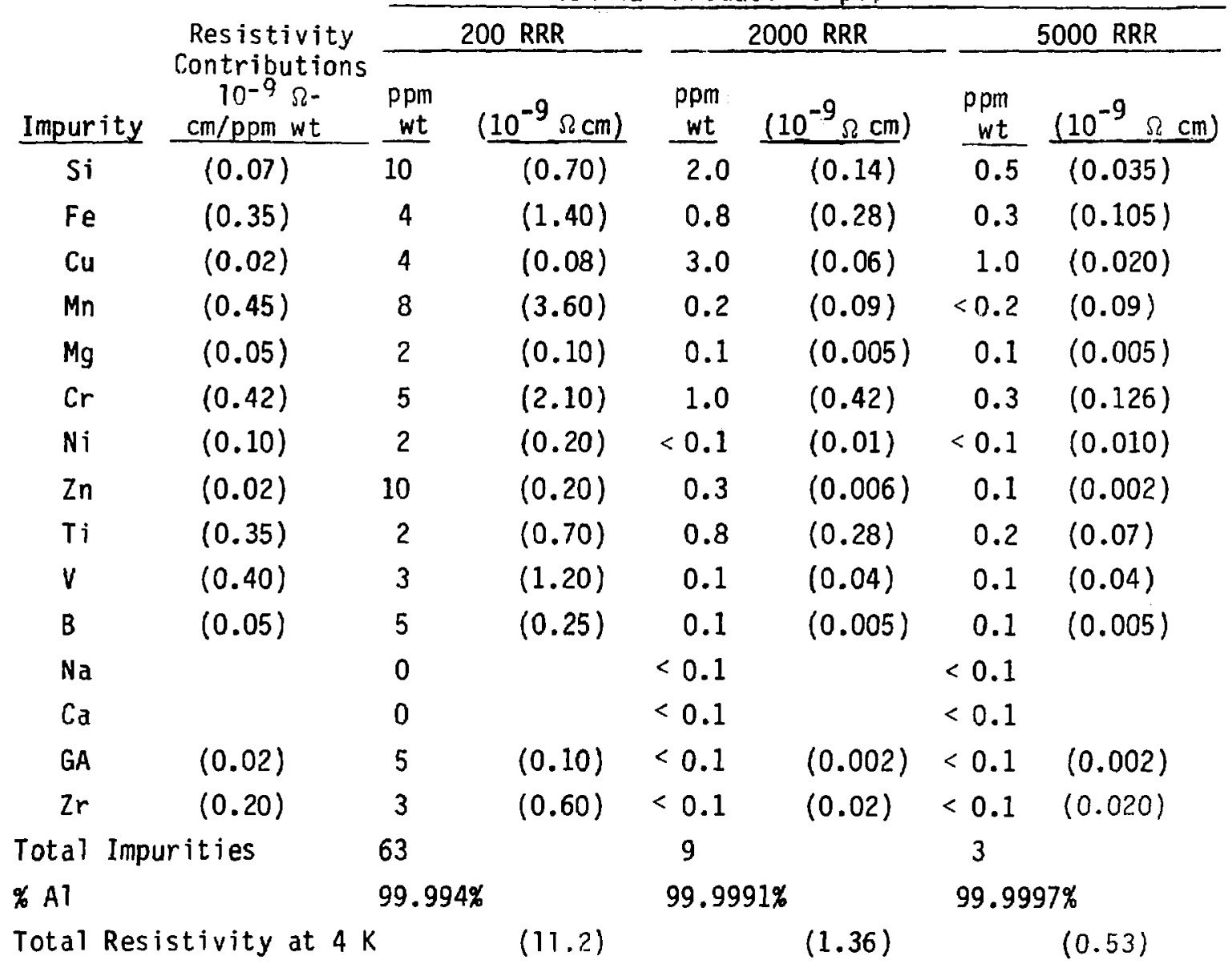

$R R R$

$$
\frac{2.71 \times 10^{-6}}{11.2 \times 10^{-9}} \cong(240) \frac{2.71 \times 10^{-6}}{1.36 \times 10^{-9}} \cong(2000) \frac{2.71 \times 10^{-6}}{0.53 \times 10^{-9}} \cong(5000)
$$

Procedures used at the Aluminum Company of America to determine purity include measurement of resistivity at $4.2 \mathrm{~K}$, solid-source mass spectrographic techniques $^{1}$ which are sensitive to $0.1 \mathrm{ppm}$ for most impurities, and direct reading emission spectrometric techniques ${ }^{2}$ which are sensitive to $1 \mathrm{ppm}$ for most impurities. 
B. Purification Processing

The purification processing used for this study is proprietary information of the Aluminum Company of America. No description of the processing is contained in this report.

TABLE B-II

SELECTED PILOT PLANT RESULTS

DIRECT READING, EMISSION SPECTROMETRIC ANALYSES

$(\mathrm{ppm}, \mathrm{wt})$

Lot $458631 \quad$ Lot $479662 \quad$ Lot $479736 \quad$ Lot 479736

$-33$

$-27$

$-33$

$\mathrm{Si}$

1

0

0

$\mathrm{Fe} \quad 1$

0

$\mathrm{Cu} \quad 3$

2

0

0

$\mathrm{Mn} \quad 0$

0

2

1

$\mathrm{Mg} \quad 0$

0

$\mathrm{Cr} \quad \mathrm{O}$

1

$\mathrm{Ni} \quad \mathrm{O}$

0

Zn

0

0

$\mathrm{Ti} \quad 0$

0

0

$\checkmark \quad 0$

B $\leq 1$

Be 0

$\leq 1$

0

Ga 0

0

Zr 0

0

$\mathrm{Na} \leq 1$

$\mathrm{Ca}$

$\leq 1$

Measured

RRR

2270

2420

2610

*Not measured 
The purification steps have been tested successfully in both bench and pilot plant studies conducted at Alcoa Laboratories and funded solely by the Aluminum Company of America. All pilot facilities were operated for at least $2.5 \mathrm{yrs}$, and $\sim 6000 \mathrm{~kg}$ of $99.999 \%$ aluminum were produced. The RRR ranged from 1000 to 2600. in additional cycle of processing through one unit is required to obtain 5000 RRR. Some selected pilot plant results are shown in TableB-II. It is reasonarly certain that scaling to commercial sizes can be accomplished, and economic sizes for commercial-scale equipment have been determined from the pilot effort.

For each purity case, processing combinations were selected that will meet the purity requirements and achieve a minimum production rate of $1 \times 10^{6}$ $\mathrm{kg} / \mathrm{yr}$. Optimum commercial unit sizes were established for the cost study and multiple units were used as required. For the 200-RRR and 5000-RRR cases, a reasonable match was achieved for the required total production rate and the desired unit sizes for the purification steps. For the 2000-RRR case, a mismatch was observed for one purification step in that the economic unit size has excess production capacity. Three options available to handle this situation are (1) the size of the unit can be reduced, (2) it can be shut down periodically and the manpower used elsewhere, or (3) the unit can be used for other purposes associated with aluininum production. The third option was chosen because unit size is critical and shutdowns are wasteful and lead to early failures. Although the full capital costs for this unit are contained in the 99.999\% aluminum costs, the other costs have been prorated as required.

\section{Feed to Purification Processes}

For all three purity levels, the preferred feed is a premium smelting grade aluminum, a nominal $99.9 \%$ aluminum. An expected composition and tentative limits for this feed are shown in Table B-III. Aluminum of this purity and better is commercially produced in controlled smelting cells where ore sources and other materials are selected to limit the impurity content of the metal produced. The purification processing can use feed aluminum with impurity concentrations considerably higher than the tentative limits shown in Table B-III; but feed metal of this purity currently leads to the lowest overall costs for producing extreme-purity aluminum. For production rates of $1 \times 10^{6} \mathrm{~kg} / \mathrm{yr}$ and much higher, ore sources are not considered a limiting problem. 
TABLE B-III

ALUMINUM FEED COMPOSITION

$\begin{array}{lll} & \begin{array}{c}\text { Nominal } \\ \text { (wt\%) }\end{array} & \begin{array}{c}\text { Tentative Limit } \\ \text { (wt\%) }\end{array} \\ \mathrm{Si} & 0.040 & 0.080 \\ \mathrm{Fe} & 0.060 & 0.100 \\ \mathrm{Cu} & 0.001 & 0.0040 \\ \mathrm{Mn} & 0.0008 & 0.0012 \\ \mathrm{Mg} & 0.0002 & 0.001 \\ \mathrm{Cr} & 0.0005 & 0.0007 \\ \mathrm{Ni} & 0.001 & 0.010 \\ \mathrm{Zn} & 0.003 & 0.005 \\ \mathrm{Ti} & 0.003 & 0.005 \\ \mathrm{~V} & 0.003 & 0.005 \\ \mathrm{~B} & 0.001 & 0.005 \\ \mathrm{Na} & 0.0000 & 0.003 \\ \mathrm{Ca} & 0.0000 & 0.004 \\ \mathrm{Ga} & 0.010 & 0.020 \\ \mathrm{Zr} & 0.002 & 0.004\end{array}$

If premium smelting cell metal should become restricted because of ore source limitations or high demand, operating parameters of the purification units and processing schemes can be adjusted to accept lower grade aluminum. The cost impact would be dependent on the impurity problem and the RRR desired. Manganese and chromium would be of greatest concern because of their 1 arge contribution to the residual resistivity of aluminum and because they are low in the proposed feed aluminum. In very adverse situations, additional purification capacit; would have to be added for all three cases.

D. Plant Location

There are several advantages to locating an extreme-purity facility at an existing smelting plant. These include (1) the proximity to smelting cells, (2) the availability of trained personnel, (3) the availability of on-site analytical facilities, and (4) the possible use of material handling equipmert and storage facilities. 
There is only one situation currently recognized that would give an advantage to locating the plant at the manufacturing site for the SMES devices. The extreme-purity aluminum is obtained molten from the last purification process. If SMES manufacture used molten aluminum and could be coordinated with the purification facility, remelting (and possible contamination) of extreme-purity aluminum could be avoided. This is considered important for the 2000- and 5000-RRR cases where contamination of $1.0 \mathrm{ppm}$ of a critical impurity would dramatically reduce the electrical purity of the product. This approach would also reduce the cost of purification facilities by eliminating capital for casting operations. Because current concepts for manufacturing SMES devices do not use molten aluminum, the cost study results are based on the purification facility being located at an existing smelting plant.

Fabrication processes, such as extrusion, have been tested without known contamination of 2000-RRR aluminum and do not pose a restriction on facility location.

E. Cost Study Results

The final results of the cost study are tabulated in Table B-IV for the 30-yr sustaining market and in Table B-V for the 2-yr market. All numbers are based on 1978 dollars. The sales price is the amount required to purchase the product in the simplest form of 50-1b remelt ingots. It does not include shipping costs or taxes, charges for fabrication of shapes, or casting charges for producing high-quality fabricating ingots. A11 costs of producing and purifying the aluminum plus profit are totaled to obtain sales price.

The total investment or "cost of facilities" figures are given in millions of dollars and represent the total money required to produce final designs, procure materials, provide inventories, build all facilities, and start the plant. Costs described as "10\% Interest/Amort." in the tables are strictly depreciation and the cost of money and do not include profit. They are given per kilogram and pound of final product. The power and fuel costs are the total required for purification and are also given per kilogram and pound of final product. Except for "Sales Price," all items do not contain any costs for producing the premium smelting grade aluminum recommended as feed for the purification facility. See Sec. C. All information in the tables is provided as a range representing uncertainties. In order of importance, these are associated with (1) consistency of production and contamination effects, (2) potential scaling problems, (3) manpower requirements, (4) analytical 
TABLE B-IV

COST STUDY SUMMARY, 30-YR MARKET, PRODUCTION $1 \times 10^{6} \mathrm{KG} /$ YR

\begin{tabular}{|c|c|c|c|}
\hline Purity Cases & $\begin{array}{l}200-R R R \\
\text { Aluminum }\end{array}$ & $\begin{array}{l}2000-R R R \\
\text { Alum inum }\end{array}$ & $\begin{array}{l}5000-R R R \\
\text { Al uminum }\end{array}$ \\
\hline \multicolumn{4}{|l|}{ (1) Sales Price } \\
\hline$\$ / \mathrm{kg}$ & $2.60-4.00$ & $6.60-19.80$ & $8.80-44.00$ \\
\hline$(\$ / T b)$ & $(1.20-1.80)$ & $(3.00-9.00)$ & $(4.00-20.00)$ \\
\hline \multicolumn{4}{|l|}{ 2) Investment (million \$) } \\
\hline \multicolumn{4}{|l|}{ (Cost of facilities) } \\
\hline (a) Construction & $2.3-3.4$ & $8.1-16.2$ & $12.0-36.0$ \\
\hline (b) Engineering & $0.3-0.4$ & $1.3-2.6$ & $1.7-5.1$ \\
\hline (c) Working capital & $0.2-0.3$ & $0.8-1.6$ & $0.8-2.4$ \\
\hline (d) Start-up expense & $0.1-0.2$ & $0.5-1.0$ & $0.7-2.1$ \\
\hline Tota1 & $2.9-4.3$ & $10.7-21.4$ & $15.2-45.6$ \\
\hline \multicolumn{4}{|l|}{ 3) $10 \%$ Interest/Amort. } \\
\hline$\$ / k g$ & $0.4-0.66$ & $1.65-3.30$ & $2.33-7.00$ \\
\hline$(\$ / 1 b)$ & $(0.20-0.30)$ & $(0.75-1.50)$ & $(1.06-3.18)$ \\
\hline
\end{tabular}

(4) Power and Fuel Costs

(Purification on $7 y$, no smelting)
$\$ / \mathrm{kg}$
$0.20-0.29$
$0.55-1.10$
$0.79-2.38$
$(\$ / 1 b)$
$(0.09-0.13)$
$(0.25-0.50)$
$(0.36-1.08)$

requirements, (5) profit incentive to enter the business, (6) purchased raw material cost variations, and (7) feed metal variations.

To explain the use of these uncertainties, the 2000-RRR purity case with a 30-yr sustaining market will be used. The lower value in the range for this case for all items in Table B-III is based on the average productivity of ongrade aluminum obtained during the best 6-month period of pilot plant operations. The major reason for increasing the capital, interest/amort., power costs, and most other costs is inconsistency in production and contamination. effects. These are taken together because loss of production is sometimes due to contamination problems. Calculation of this effect was based on the production capability of the pilot plants for the entire operating period lover 
TABLE B-V

COST STUDY SUMMARY, 2-YR MARKET, PRODUCTION $1 \times 10^{6} \mathrm{KG} / \mathrm{YR}$

\begin{tabular}{lcccc}
\multicolumn{1}{c}{ Purity Cases } & $\begin{array}{c}200-R R R \\
\text { Aluminum }\end{array}$ & $\begin{array}{c}\text { 2000-RRR } \\
\text { Aluminum }\end{array}$ & $\begin{array}{l}\text { 5000-RRR } \\
\text { Aluminum }\end{array}$ \\
\cline { 1 - 1 } $\begin{array}{l}\text { (1) Sales Price } \\
\$ / \mathrm{kg}\end{array}$ & $4.40-6.60$ & $13.20-39.60$ & $17.60-88.00$ \\
$(\$ / 1 \mathrm{~b})$ & $(2.00-3.00)$ & $(6.00-18.00)$ & $(8.00-40.00$
\end{tabular}

(2) Investment (million \$)

(Cost of facilities)
(a) Construction
$2.3-3.4$
$8.1-16.2$
$12.0-36.0$
(b) Engineering
0.3-0.4
1.3-2.6
1.7-5.1
(c) Working capital
0.2-0.3
0.8-1.6
0.8-2.4
(d) Start-up expense
$0.1-0.2$
$0.5-1.0$
$0.7-2.1$
Total
$2.9-4.3$
$10.7-21.4$
15. $2-45.6$

(3) $10 \%$ Interest/Amort.

$\$ / \mathrm{kg}$

$$
1.67-2.51
$$

6.16-12.32

$8.76-26.27$

(\$/1b)

$(0.76-1.14)$

(2.80-5.60)

(4) Power and Fuel Costs

(Purification only,

no smelting)
$\$ / \mathrm{kg}$
$0.20-0.29$
0.55-1.10
$0.79-2.38$
$(\$ / 7 b)$
$(0.09-0.13)$
(0.25-0.50)
(0.36-1.08)

$2.5 \mathrm{yrs})$. Also contained in the high number for capital, interest/amort., and power costs are potential scaling problems and feed metal variations insofar as they could reduce the productivity or life expectancy of the units. These productivity uncertainties account for $\$ 3.00 / 1 \mathrm{~b}$ of the sales price range quoted for the 2000-RRR, 30-yr case. The balance of the range is due to uncertainties that affect operating costs but not productivity. There is concern over scaling chänges that can increase the loss of materials used in the processes. These would increase the operating costs and, in one case, give an environmental problem that is solvable, but only with added expense. other uncertainties influencing operating costs but not productivity are 
(1) manpower requirements for the commercial units, (2) quality control situations requiring extra analytical costs to identify and soive problems, and (3) variations in the cost of materials purchased from outside vendors. The top end of the range also includes a higher profit margin because of the relatively small size of the business venture.

The results of these studies indicate that extreme-purity aluminum can be produced and sold for much lower prices than the current market situation would indicate. Currently 99.999+ aluminum with an RRR of 2000 can sell for greater than $\$ 40 / 1 b$ (unfabricated piece). With this processing and a longterm market of $1 \times 10^{6} \mathrm{~kg} / \mathrm{yr}$, this material should be priced between $\$ 3.00$ and $\$ 9.00 / 1 \mathrm{~b}$. Even the 2-yr market case for 2000-RRR aiuminum gave a price between $\$ 5.00$ and $\$ 18.00 / 1 \mathrm{~b}$, which is still a major improvement.

These processes were developed for large 99.999 aluminum market situations $\left(>1 \times 10^{6} \mathrm{~kg} / \mathrm{yr}\right)$ and depend on economies of scale for major cost reductions. But even at the pilat-plant scale, the processes that were built actually produced a significant cost improvement over existing comercial technology.

\section{F. Potential Cost Reductions}

This report documents expected costs for a production rate of $1 \times 10^{6}$ $\mathrm{kg} / \mathrm{yr}$. Further economies of scale can be realized at even higher production rates for all three purity cases. If large markets existed for a range of purities from 200 RRR to 5000 RRR, additional cost savings could al so be realized. The processing steps can be combined in such a manner that one or more steps are eliminated because of synergistic effects. Also, a contamination accident, which reduced tons of 5000-RRR metal to 1000-RRR metal, would not be as catastrophic if the 1000-RRR material could be sold with a reasonable metal value. An example of a future market area that could require large amounts of 1000 -RRR aluminum is the nuclear fusion reactor. 3

A current development effort at Alcoa Laboratories holds promise for dramatically increasing the productivity and reducing the energy costs of the most expensive processing step used for this study. Further nrogress in materials technology will also be beneficial. 


\section{REFERENCES}

1. Arthur J. Ahearn, Trace Analys is by Mass Spectrometry (Academic Press, New York and London, 1972).

2. "Aluminum and Its Alloys, by the Point to Plane, Nitrogen Atmosphere, Spark Technique Using an Optical Emission Spectrometer," ASTM Method E-2, P5.

3. A. G. Craig, Jr., R. A. Kramer, D. J. Lege, C. N. Cochran, and E. C. Franz, "Extreme Purity Aluminum for Fusion Reactor Blankets," Aluminum Company of America (June 1976). 